\title{
Myth and Antimyth in the Fictions of Socialist Realism in Albania
}

\author{
Msc. Laureta Misiri
}

misiril@yahoo.com

\begin{abstract}
The process of formation of socialist realism in literary creativity goes hand in hand with the crystallization of social awareness "down", within the psychology of the masses and "up", with the strengthening ideological party institutes of state. Endless discourses among the circles of artists on this plane, so competent is the new artistic unity as "the soc-realistic method" that obtained the status of state doctrine. In 1936 the Soviet government undertook measures to implement the undisputed total soc-realistic method all the arts in the USSR. Socialist realism becomes the dominant term in the science of Soviet literature and art sciences from the thirties to mark "basic approach" which "requires the artist to introduce the concrete historical truth of reality in its revolutionary development", so the literature had to be created with the task of educating the workers in the spirit of socialism. The notion aesthetic "realism" was related to defining "socialist", brought the practice of literature and arts submission to ideology. Demands of using the socialist realism techniques in fact became an obstacle, an anxiety to halt creativity that for years was avoid against the spiritual life of the people, so the writers created in the majority mediokre works of conformist who became propaganda trumpets. In the late ' 80 s realism becomes literary and historical term, but in the embryonic stage of many characteristics, the soc-realism literature is determined as "heroic realism", "monumental", "social", "biased" and as if the category of "folk" is the basic principle of a work of art where the mythical watches in the mirror its other part of the medal.
\end{abstract}

Keywords: Myth, Antimyth, Fictions, Socialist Realism, Albania

\section{Introduction}

The myth lies at the core of literature, it is the premise of the genesis and the paradigm of a fiction and the same time of all literary books together, forming a palimpsest. Everyone occurs inevitably to deal with variations of the myth when studying literature and it is explored deeply by different anthropologists, and literature critics as well.

The relations between time and space in myth and literature, we can describe, as the same time as in the dreams, so, if we analyze symbols in dreams, in this way we can analyze the internal time and space connected with the movement and the state at the same time in literature. Thus, referring to Erich Fromm, who tells that it is a lost language for modern civilizations communicating with dreams, we can tell that in some plans the mythical, poetic, philosophical and psychological and literature have a lot of things in common.

\section{Paradoxes paralyzing literature in Albania in socialist political system}

Obviously factors of prohibition of literature and its obstruction by the socialist method dictated by the politic of the time in the years 1949-1952 were paradoxical circumstances; when the terror started from the League of Albanian Writers with the sack of Malëshova and further Trebeshina and so went on.

At the time when this method rule in most of the literature, in Albania, different authors faced that, in their own manners. Thus, during the ' 50 s new orientation in the field of Albanian literature, as in thematic level, and the methods of creative eve obviously put in pressure the writers, first thematically in the echo of the victory of the National Liberation War, and actuality was reduced mainly in black and white and with the beginning of the ' $60 \mathrm{~s}$. In this context it should be mentioned, that there were the writers as Petro Marko in 1958, when published his novel view "Hasta la Vista", brought another point of view in the Albanian novel, and moreover original sensitivity to the appearance of the characters in his novels which penalized him as a writer. 
Later art sprained, it was used in the worst way and it was a function of political propaganda, as some artists were introduced, violently as cliché of socialist realism where the best feeling of civilization as love and the intima world of the human was violated.

While the liberty is hit, exactly when the thread of artistic creation becomes impossible entered and passing the fence of socialist realism, it is needed to be transformed or into megaphones to spread the utopia and stupid topics which had to have a significant influence on the consciousness of the masses., or to camouflage into classic symbols of myths to survive the real literature in the sense of what writer wants to, as Kadare did. Different authors knitted the thread of prose in Albania as Dritëro Agolli, Dhimitër Xhuvani, Ali Abdihoxha, Skënder Drini, Sabri Godo, Vath Koreshi etc., while at the top of poetry lyric were Fatos Arapi, Ismail Kadare and Dritëro Agolli, as a new generation of talented poets.

Sometimes writers were heroes, somehow justified about what they did, because the dictatorship did not leave much choice, but the worst was the silence or rejection of artistic creation of Albanian writers, because the writer is as prophet who endure pain to say the words of the truth, as promethean myth transmits to all generations since the antiquity.

This false philosophy of life, represented also in literature survived by lightening the socialist censorship, created models always in cause-effect relationships of structure, in view of the dynamic structure of the movements within it as the expression of a controversy religion, a religion of becoming a martyr, an extremism in sacrifice, because even though all the Albanian became atheists, they had to believe in the labor party, and die for the masses in work.

All life experiences, reflection of social awareness, where they felt the positive values of heroes, expressed artistically gave the configuration in the understanding of the life. The critical thinking, theoretical and aesthetic of that time as well as restricted the line of the Albanian novels based in the principle of ideas, characters, conflicts, forms the composition, flow of the narrative, features stylistic and linguistic up since in detail, comprehensive to the soc-realistic method. However the criticism of the time of socialist realism in Albania didn't lack, it served as a censor based on a semi pragmatic socialist realism platform and the articles in the newspapers of the time, most discussed about novels about the development of a large industry reflected in the behavior of the working class, and the positive hero, the bravest one mustn't fear the death.

In all the novels the heroic force was presented in the superlative form, to sacrifice the own life for the others, it has to do with the building of the industry of Albanian country. The literature of socialist realism has pictured the Albanian society better than it was in reality, given work as novels and stories of Dhimitër Xhuvani, some of the stories the Anastas Kondo. There were also monuments work of epic that dealt specifically through various Albanian history who ran in the time between the two world wars, a choice option to rescue, as Jakov Xoxa. It is worth mentioning what choice did Lasgush Poradeci. This great poet was silent with the inspiration that decayed in the chest, but if we read the Lasgush Poradeci today our senses will be deeply alive and untainted by the folly of socialist realism in a matter as aesthetic, as well as the evaluation criteria to recognize our ideals and dreams and through them the goals, existential and morality of human society in general.

\section{The salvation of writer because of myths and symbols}

Since Hesiod, Homer, till Ali Podrimja, Kasem Trebeshina, Konica, Migjeni till Kadare literary critic studies have been focused on myth thematic and conceptual plan, the presence of myth as a significant contribution to the promotion of philosophy of life. Literary studies distinguished by the system of knowledge and literary theories, the most advanced scientific methods, building author makes creative logic through their fiction, so they build their own myth, which may be either real, or fake one. The phenomenon range from the origin of the meaning of myths and mythology to reach to the problems of modernism and postmodernism in the literature.

The author is always with his presence, the subject and the object of his fiction indicating his subjective feelings and point of views, aiming always to bring out the foreground himself. His id in war with his ego goes beyond wanting to create 
something else, perhaps an image that we have never encountered before. Mystification begins here. The author says that it is the work, and believe or not building his own myth makes his work immortal after tormenting idea if it is worth or not.

It is in human nature to seek immortality. Life and death, being mortal and eternity are the author's existential dichotomies. Thus referring to Albanian authors in the majority of their work has made in order to serve something utilitarian whether an idea as homeland, language, collective essence, ideology, doctrine, ethnicity etc. The Albanian author learned to be social activist, a warrior, imprisoned, liberator, either censor, or censored, persecutor and persecuted, antifascist, anticommunist, cynical, aggressive, peaceful, indifferent, dissatisfied.

Stressing the fact that being atheist means that, either you are the god, or you are an abandoned orator. Maybe it is misunderstood, misinterpreted infinitely, but the author in Albania it was a conductor of a religion life evoking the surprise a wonderful life never happened before in capitalist society and if not, he would be anathematized.

Albanian authors with their further creations of I. Kadare, D. Agolli, etc who consolidated the Albanian traditional poetics of the novel, creating types of novel, according polyphony of voices did the typology best novel in a national literature introducing a fable as a basis on which character were established on a prototype of its time, but referring Agron Tufa opinion the antic people who created myths, didn't call fantasy they really believed them, so it was the idea of the Albanian authors to create a myth of a different living, a Narcisse mirror and to make ourselves proud.

It can be illustrated precisely by the actions and feelings and thoughts of the characters, and somehow nothing to do with art, not the sense, but something educational and civic literary. The novels, portrayd more realistic physical and spiritual characters confirmed a whole internal study of virtues of sacrifice, not more, even though it was obvious immediate need for unfolding retrospective though tradition, and if Gerard Genette considers literature as art of artistic criticism seems to be a reasoned judgment of this discourse. To decide then how ever be used to reevaluate this kind of literature, because opposing the author and the reader who many times imposes author according to Eco who sometimes behave as lazy, hypocritical and superficial, and the same time see the author as the embodiment of his taste changes.

As we know after ' 90 years through talented writers, across Europe, Albanian literature began to penetrate the spirits and the sensibilities of the creative Albanian literary, as Konica, Koliqi, Kuteli, etc recorded some of the highest pinnacle of Albanian literature, types and genres, such as epic, literary criticism etc. Designed as for Albanians, as for foreign readers, the writers contunue to give us a full encyclopedia for Albania and its people. A mosaic of history and culture, language and literature, spirituality and psychology of the world's Albanians, with an extensive information and in-depth knowledge, harmonizing scientific objectivity with an entertaining account of the author highlights the individuality and the nature of the Albanian people not only see itself, but also in Balkan and European context.

Now gathering all in drawers books, we assume that creative inspiration was not halted immediately establishing communist rule, abroad Albania, Kuteli continued to be a natural continuation of war by publishing literature whenever the omitted censorship. Albanian literature novel bloomed between '60s and '90s of the twentieth century, explained the process of social, cultural, educational, in the eyes of the politic ideology of that time etc. but at the same time left the space blank so long for the reader desired to a subcoschient world of a writer who really discovers what a reader needs.

Being a writer in Albania during the ' 50 and ' 90 s there was a maximum pain, self-sacrifice, and a truly prophetic foresight, some might have been real writers, because only they can feel that freedom was near, those does not make any compromise in their act of creation; their freedom and creative spirit was already summarized in hidden parts of their unconscious as dreams exist and communicate with us in silence inside the walls, where the only noise of their pen exists. Imposing within myths which someone created was much more than the clap propaganda trumpets the realsoc who today are experiencing the death of their pseudo artistic creativity, death of what had considered genuine literature. For such writers freedom came to punish their fiction. The need for an inner life, to develop cultural and political and creation of idealism, and being national remain ideas on sustainable if the European models and the few Albanian to overcome the boundaries that often times leads to isolation. New "albanologists" today, are trying to bring social, ideological arguments to attack the Albanian language and its antiquity, Skanderbeg and its history on behalf of waste thought. As I highlighted the some problems of the literature in the last century in Albania, not been in equilibrium, but today, Europe and the fascination towards harmony finds the majority of Albanians, convinced that the nation appears on the beliefs, here it is found in compliance with the best literary thought. 
There is not only some masters of writing Albanian literature which is all bent historical consciousness and nurturing to give Albanians and the entire planet in elevation. This deep awareness of the national historic gave this sound of the prophetic voice of a spokesperson who protects his tribe in the depths of its most visible and hidden depths that are shocking. Identity issues are a phenomenon associated with the modernization process of itself society and in this process the albanian writer must be first intellectual, feeling lucky for his identity and building his own myth in the wake of the wonderful fiction of this country, of his dispute in literary terms in the match the fate of the nation in its crucial historical moments.

\section{BIBLIOGRAFI}

[1] Eco, Umberto, "Sugli specchio e altri sargi", Bompiani, Milano 1990

[2] Fray, Northrop, "Anatomy of critism", New Jersey Princeton University, Princeton 1990.

[3] Fromm, Erich, "Gjuha e harruar", Dituria, Tiranë, 1998.

[4] Frye,Northtrop, "Anatomy of Critizm", New Jersey Princeton University, Princton 1990, f 122

[5] Hamiti, Sabri, "Letërsia moderne shqipe", Tirane 2009.

[6] Qosja, Rexhep, : Shkrimtarë dhe periudha,Shtypshkronja "Mësonjëtorja", Tiranë, 2005

[7] Sinani, Shaban: "Për letërsinë shqipe të shekullit XX",Shtëpia Botuese Naimi,2010

[8] Suta,Blerina: Pamje të modernitetit në letërsinë shqipe, Proza e shkurtër e Koliqit Kutelit dhe Migjenit,Onufri,2004

[9] Tufa, Agron: Kuja e Mnemozinës, Tiranë, 2010

[10] Zherar Zhenette, "Figura", Rilindja, Prishtinë 1985, f. 185. 